\title{
The Effects of Corporate Governance and Ownership on the Innovation Performance of Chinese SMEs*
}

\author{
Daniel Shapiroł Yao Tang‡ Miaojun Wang§, and Weiying Zhang
}

January 22, 2015

\begin{abstract}
Abstract: We investigate the degree to which corporate governance and ownership affect the innovation performance of firms in China with a particular focus on privately owned small and medium enterprises (SMEs). Using the appropriate theoretical frameworks, we derive hypotheses regarding the impact of ownership concentration, board size and composition, and the background of the CEO on innovative activity. These hypotheses are tested using a unique sample of 370 mostly private and relatively small Chinese firms in Zhejiang province, for the period 2004 to 2006. Using two measures of innovation, invention patents and new product sales, and a variety of estimation methods appropriate to each measure, we find limited evidence that corporate governance affects innovation performance, but the results do depend on the measure of innovation. In general, the results suggest that for this sample, corporate governance and ownership affect innovation activity more strongly when innovation is measured by patenting activity, rather than new product sales. We conclude with a discussion as to why this might be.
\end{abstract}

JEL classification: M1, M2, O3

Keywords: Chinese SMEs, corporate governance, innovation, patents, and new product sales

\footnotetext{
*Miaojun Wang is grateful for the financial support from the Ministry of Education of China (Grant 07JJD790146) and from Zijing Plan, Zhejiang University. We thank Nathan T. Joseph for his excellent research assistance and participants at the 2013 Academy of Innovation and Entrepreneurship annual conference for their comments and suggestions. All errors are ours.

${ }^{\dagger}$ Beedie School of Business, Simon Fraser University, 500 Granville St., Vancouver, BC V6C 1W6, Canada. E-mail: dshapiro@sfu.ca.

${ }^{\ddagger}$ Corresponding author. Department of Economics, Bowdoin College, 9700 College Station, Brunswick, Maine 04011-8497, USA. Email: ytang@bowdoin.edu.

${ }^{\S}$ Center for Research of Private Economy, Zhejiang University; College of Economics, Zhejiang University, Zhejiang, China. Email: mervinjun2000@vip.sina.com.

"Guanghua School of Management, Peking University, Beijing, China. Email: wyzhang@gsm.pku.edu.cn.
} 


\section{Introduction}

Innovation is a key determinant of the competitive performance of both countries and firms, and is particularly important to emerging economies as they attempt to raise productivity and incomes. As an emerging economy and also the second largest economy in the world, China recognizes the critical importance of innovation and has adopted policies to encourage innovative activities (Breznitz and Murphree, 2011) ${ }^{1}$, including innovation by small and medium enterprises (SMEs) (Xinhua, 2013). Existing evidence suggests that research and innovation activities have indeed increased substantially over the past decade (Hu and Jefferson, 2009; Huang, 2010), and researchers have now begun to study the determinants of innovation in China, with a particular focus on the effects of R\&D. Empirical studies (Jefferson et al., 2006; Sun and Du, 2010; Zhao et al., 2014) show that in China, the R\&D activities of firms have significant and positive effects on innovation and other measures of firm performance.

Despite these efforts, substantially more research is still required to understand fully what drives the innovation process in China (Yang et al., 2012). Researchers have therefore begun to study other mechanisms that contribute to the innovation performance of Chinese firms. These mechanisms include access to foreign knowledge (Wang and Kafouros, 2009; Li, Chen, and Shapiro, 2010) and various incentive schemes (Chow and Liu, 2007; Zhang and Li, 2009; Li et al., 2010). In this study, we add to this literature by examining the role of corporate governance and ownership as determinants of innovation activity in mostly privately-owned SMEs in China.

There is considerable evidence, mainly from developed countries, that corporate governance and ownership affect innovation outcomes (Casper and Matraves, 2003; Sapra, Subramanian, and Subramanian, 2011; Belloc, 2012 provides a recent survey). This general literature suggests a number of channels through which corporate governance (including

\footnotetext{
${ }^{1}$ President Hu Jintao suggested that enhancing China's ability in independent innovation is the core of the country's national development strategy (Hu, 2007).
} 
ownership identity and concentration, board size, and structure) affects innovation. First, large, long-term block owners are providers of "patient capital". For example, institutional investors with a long investment horizon (Bushee, 1998; Eng and Shackell, 2001; Aghion, Van Reenen, and Zingales, 2013) and owners who take control through leveraged buyouts (Lerner, Sorensen, and Stromberg, 2008; Ughetto, 2010) are more likely to commit resources to innovation. Second, a dominant owner has the incentive to monitor the innovative efforts of management and is also more likely to commit to long-term objectives like innovation (Hill and Snell, 1988; Baysinger, Kosnik, and Turk, 1991). Third, an effective and well structured board of directors, including one that splits the positions of Chair and CEO and has independent members, can enhance innovation by providing monitoring and access to outside resources (Hill and Snell, 1988; Lacetera, 2001).

However, in emerging economies where the general financial and institutional environments are less developed (La Porta et al., 2000; Heugens, Van Essen, and van Oosterhout, 2009), there is evidence suggesting that corporate governance practices perceived to be effective in developed countries may not be readily translated to emerging market economies (Claessens and Fan, 2002; Gibson et al., 2003; Heugens, Van Essen, and van Oosterhout, 2009; Van Essen, van Oosterhout, and Carney, 2012). In the particular context of China, Chen, Li, and Shapiro (2011) find that corporate governance practices recommended by the OECD do not improve the financial returns of Chinese firms. Thus, it is important to determine whether these findings extend to the case of innovation in China, taking account of the institutional specificity of the Chinese economy.

There is in fact little research on the relation between corporate governance and innovation in emerging economies. Existing studies (Choi, Lee, and Williams, 2011; Choi, Park, and Hong, 2012; Chen et al., 2012; Deng, Hofman, and Newman, 2013) focus mainly on the effects of ownership structure, and do not consider the broader components of corporate governance. An exception is $\mathrm{Wu}$ (2008) who finds that managerial ownership 
and board competence have positive effects on the introduction of new products in Taiwan. The understanding of the general effects of corporate governance on innovation in emerging economies, including China, is therefore very limited.

Another limitation of the literature on firm innovation in China is that existing studies are typically based on samples of listed firms and other large firms, often with significant state ownership (Li, Chen, and Shapiro, 2010). Compared to private SMEs, these firms have access to better financing and sometimes receive preferential support from the government. However, private enterprises in China have emerged as the dominant source of invention patents (Huang, 2010), and the Chinese government has recognized the economic importance of private small and medium enterprises (SMEs) as drivers of innovation (Xinhua, 2013). Therefore, it is hard to discuss innovation in China without considering SMEs, notably those that are private, a point recently emphasized by Zhu, Wittmann, and Peng (2012).

Accordingly, we address the following research question: does corporate governance (including ownership structure) contribute positively to innovation activities of SMEs in the emerging country of China? In answering this question, we focus on the effects of three internal corporate governance mechanisms: ownership concentration, the board of directors, and whether the $\mathrm{CEO}$ is an outsider. Mindful of the important features of SMEs in China, which include concentrated ownership (Xu and Wang, 1999), restricted access to external resources; and the absence of the market for corporate control (Chen, Li, and Shapiro, 2011), we apply elements of standard agency theory Jensen and Meckling (1976), resource-dependence theory (Pfeffer and Salancik, 2003), and principal-principal theory (Chen, Li, and Shapiro, 2011), in the context of China to generate a series of testable hypothesizes. Specifically we hypothesize that (1) innovation first increases with ownership concentration because such concentration allows the owner to commit to longrun and risky innovation projects, but this positive effect declines at a higher levels of 
ownership concentration because additional concentration beyond a critical level provides little extra incentive for the largest owner to innovate; (2) a large board and the presence of independent directors contribute positively to innovation because they help the firm to access critical resources and also improve monitoring; and (3) an external CEO enhances innovation by ensuring professional management of the company.

We test these hypotheses using a sample of 370 firms in Zhejiang province, China between 2004 and 2006. As we discuss in detail below, Zhejiang province is known for its entrepreneurial culture, and the firms we study are primarily private, and classified as small or medium in size. We recognize that the sample is not necessarily representative of SMEs in China. However, because SMEs in Zhejiang are arguably among the most dynamic and innovative in China, our analysis of Zhejiang contributes to an understanding of the mechanisms that can improve the innovative potential of all Chinese SMEs.

We use two measures for innovation, the number of new patents granted between 2004 and 2006, and annual new product sales. ${ }^{2}$ The former measure will include potential process and product innovations, while the latter covers actual new products. We recognize that there is no perfect measure of innovation, and discuss these two measures below. We also employ estimation techniques that are appropriate to the characteristics of the relevant dependent variables, and also use alternative specifications to ensure the robustness of our conclusions.

Overall, we find limited evidence that corporate governance affects innovation performance, but the results do depend on the measure of innovation. Some dimensions of corporate governance have significant effects on the number of new invention patents granted during the period studied. We find that patent activity at first increases with ownership concentration but ultimately the positive effect weakens, as hypothesized. Similarly, we find some evidence that the presence of external board members enhances patenting.

\footnotetext{
${ }^{2}$ The patents here refer to those granted by the State Intellectual Property Office of China. Firms in China can acquire the designation of new products through certification by central government or provincial governments.
} 
The presence of an outsider CEO has positive effects on patenting only in the group of firms with positive counts of new patents. At the same time, we find little evidence that any corporate governance variable has a significant impact on innovation, measured by new product sales. The results indicate that the determinants of patenting, a more radical form of innovation, are different from those of new product sales, a more incremental form of innovation, and one that is possibly more responsive to pressures external to the firm (Xiao, Tylecote, and Liu, 2013).

Relative to the literature on corporate governance and innovation, our paper makes three contributions. First, we add to the growing body of research on innovation in China, by highlighting corporate governance as a potentially important determinant of innovation in firms. Second, our study offers a particular emphasis on the governance of private SMEs, the type of firms that are rarely studied in the general literature on corporate governance (Van Essen, van Oosterhout, and Carney, 2012),, and in particular in China. ${ }^{3}$ Third, by focusing on China, we test the boundaries of important claims in the corporate governance literature (Tsui, 2006), and extend the existing literature on corporate governance and innovation that focuses mainly on developed countries (Belloc, 2012).

\section{Hypothesis Development}

Innovation, defined as the development of a new product or a production process, has two important features. First, innovation often requires team production. That is, it requires inputs from multiple parties. These parties can include the owner of physical capital, managers and workers who provide the human capital, and the financial sector that provides the financing. Because the investment of these inputs is often specific to the

\footnotetext{
${ }^{3}$ Prior studies of SMEs in China often focus on other aspects of firm performance (such as market share, sales, profitability, e.g. Liu, Wright, and Filatotchev 2013), and capital structure (Newman, Gunessee, and Hilton, 2012).
} 
innovative project and irreversible, there are incentives for various parties to engage in selfserving behavior that can undermine the project (the "hold-up" problem). For instance, after R\&D workers have performed specified lab experiments and produced results, there may be disputes over the ownership and subsequent use of the intellectual property. In order for successful team production to occur, a mechanism is required to coordinate the interests of different parties. Second, the outcome of innovative activities is uncertain, but the individuals involved in innovation are often risk-averse. In particular, individuals who have little ability to reduce risk through diversification will be more risk-averse. Managers and workers may therefore prefer less risk-intensive $R \& D$ investment because they strongly dislike the income fluctuations associated with the outcome of the effort. To encourage the level of risk-taking that is efficient for the team, these individuals need to be properly motivated.

Although individuals and non-profit organizations also engage in innovative activities, firms are an important source of innovation. This is because they provide as a partial solution to the innovation problem by coordinating team production, and offering incentives for innovation (Hölmstrom, 1979, 1982; Hölmstrom and Milgrom, 1994). By shaping the coordination and incentive mechanisms, corporate governance, defined as ways in which a company is controlled and run, can play an important role in firm innovation. It offers a way to reduce the kinds of opportunism that threatens innovation and also establishes the incentives necessary to foster it (Belloc, 2012). The governance of a firm is shaped both by external factors, such as laws and the market for corporate control, and the internal design of the firm, such as the distribution of control rights and compensation. Because our sample of firms in Zhejiang arguably face the same external corporate governance environment, in this paper we focus on three important dimensions of internal corporate governance: ownership concentration, the board of directors, and whether the CEO is hired from outside. 
In our sample, the average holding of the largest shareholder is $58.64 \%$. Because this high level of ownership concentration is a prominent feature of the data and because it affects the other two dimensions of corporate governance we examine, we begin with the impact of ownership concentration on innovation.

Ownership Concentration. The general argument is that concentration in ownership can lead to more effective monitoring of management because the gain from such monitoring is large for block owners. In contrast, when ownership is diffused, each shareholder has little incentive to monitor the management, because the benefit is small relative to cost (Alchian and Demsetz, 1972; Jensen and Meckling, 1976). Consequently, diffuse ownership allows managers to engage in activities other than the inherently-risky innovation activities, while concentrated ownership may promote such activities (Hill and Snell, 1988; Baysinger, Kosnik, and Turk, 1991).

In addition, concentration in ownership promotes commitment because it is hard for large shareholders to exit the firm (Mayer, 1997). Consequently, large shareholders are more likely to engage in long-term and risky $\mathrm{R} \& \mathrm{D}$ projects. In other words, capital becomes patient allowing large shareholders to develop long-term relationships with the various stakeholders required for innovation (Driver and Guedes, 2012). At the same time, such long-term owners may also have better access to financing if they can establish a reputation for long run success (Miozzo and Dewick, 2002).

These arguments all suggest a positive relationship between ownership concentration and innovation, but they do not consider the specific institutional reality of China. In this context, and certainly in the context of our data, that reality is the high levels of ownership concentration documented above.

Even when there is a single large shareholder, at low levels of concentration, the largest shareholder has more incentive to act opportunistically in ways that limit innovation and other productive activities. They may hire unqualified individuals related to the 
controlling-shareholder (Faccio, Lang, and Young, 2001; Morck and Yeung, 2004; Su, Xu, and Phan, 2008; Young et al., 2008), engage in self-benefiting transactions (Barclay and Holderness, 1989, 1991; Barclay, Holderness, and Pontiff, 1993; Rajan and Zingales, 1998; Chang and Hong, 2000; Khanna and Rivkin, 2000), and invest less in R\&D and innovation than the optimal level (Backman, 1999; Young et al., 2008). If the largest shareholders can easily benefit from expropriation, they are less likely to support innovative activities in the company, where the returns are less certain. In China where the legal protection for property rights is weak, the expropriation of small shareholders by controlling-shareholders is particularly a realistic concern (Chen, Li, and Shapiro, 2011). In comparison, when concentration is high, the interests of the largest shareholder are mostly in line with the firms. This reasoning supports a positive ownership concentration-innovation relationship in China.

However, the effects of ownership concentration on innovation are likely to be nonlinear (Lee, 2005). Although concentration provides the largest shareholder incentive to commit to activities with long term benefits to the firm, including innovation, the effect of additional concentration beyond a critical level is likely to be small once effective control has been realized. In China, at some point highly concentrated ownership is likely to reduce innovation efforts because of increased risk-aversion arising from financial market imperfections. Financial markets are less developed in China making efficient portfolio diversification difficult. Thus, the dominant owners of SMEs often have a substantial portion of their personal wealth locked up in the firm they own and cannot diversify optimally their portfolio to reduce risk. Consequently, the dominant owner will exhibit more risk-aversion than a diversified investor (Heugens, Van Essen, and van Oosterhout, 2009), and avoid risky investment in innovation. Such risk-aversion will be more pronounced at a higher level of ownership concentration. Overall, because ownership concentration in China encourages commitment but the positive effect may diminish at higher levels of 
concentration, we hypothesize

\section{H1. Innovation increases with ownership concentration, but the positive effect of additional concentration weakens at high levels of concentration.}

We now turn to the impact of the board of directors. In the literature based on developed economies, the board of directors is seen as critical to any corporate governance structure (Fama, 1980; Adams, Hermalin, and Weisbach, 2010). First, the board of directors can align the interests of management with those of shareholders (Fama and Jensen, 1983) through the hiring, firing, and assessment of top management (Hermalin and Weisbach, 1998; Hermalin, 2005). Second, the board of directors can provide access to important external resources for the firm (Williamson, 1988; Pfeffer and Salancik, 2003). Third, the board guides the strategies of a firm (Mace, 1971; Baysinger and Hoskisson, 1990; Demb et al., 1992), including those related to innovation (Baysinger, Kosnik, and Turk, 1991).

Board Size. There are a number of reasons why a board with more directors can perform these functions better. First, larger boards are able to provide the resources and expertise to perform more and better monitoring, particularly in complex external environments (Linck, Netter, and Yang, 2008). Second, a larger number of directors allow the firm to potentially access a larger pool of external resources, including technological and financial resources that are critical for innovation. In addition, from the perspective of stakeholder theory, a larger board can accommodate more stakeholders in innovation, such as key scientists, whose influence may lead to more innovation efforts (Lacetera, 2001; Adams, Hermalin, and Weisbach, 2010). All of these arguments suggest that large boards are likely to positively affect performance in general, and innovation in particular. However, another strand of literature (Lipton and Lorsch, 1992; Jensen, 1993; Conyon and Peck, 1998; Hermalin and Weisbach, 2003) suggests that board size can have negative effects on firm performance owing to coordination and accountability problems. 
Although the literature suggests opposing effects of board size, because the SMEs in Zhejiang are characterized by highly concentrated ownership, we argue that these firms are less likely to suffer from problems related to the lack of coordination and accountability in decision making. At the same time, because private SMEs in China in general lack the same access to various innovation-related resources as state-owned enterprises and foreignowned enterprises (Handoko, Smith, and Burvill, 2014), the resource-providing function of the board will be important for these firms' innovation performance. Other things equal, this suggests that larger boards will increase the probability of broader access to innovation enhancing resources. ${ }^{4}$ Thus, we hypothesize:

\section{H2a. Innovation performance increases with board size.}

Independent Directors. The presence of outsider or independent directors is now considered a critical factor in effective corporate governance in developed countries (Fich, 2005; Fich and Shivdasani, 2006; Lehn, Patro, and Zhao, 2009; Linck, Netter, and Yang, 2009). The Company Law of China (the 2006 version) requires only listed company to have independent directors, but leaves the specifics to be decided by the State Council. The regulatory authorities under the State Council recognize and promote the use of independent directors. In particular, since 2001 all companies listed in mainland China are required to have independent directors and the number of independent directors must account for at least $1 / 3$ of the board. In our sample in which there are almost no listed firms, $48 \%$ of the firm-year observations report the appointment of independent directors even though they are not required to do so.

Independent directors play two important roles in a company. First, because of their independence, they are better positioned to monitor management (Rosenstein and Wyatt, 1990; Byrd and Hickman, 1992; Coles, McWilliams, and Sen, 2001; Peng, 2004).

\footnotetext{
${ }^{4}$ We recognize that the ability of a board to access resources may also depend on the diverse qualifications and background of board members. Because we lack data on the characteristics of individual board members, we focus on board size. However, to the extent that firms target a percentage of their board as being independent, larger boards will have more independent directors that should increase access to external resources (see below, Hypothesis $2 \mathrm{~b}$ ).
} 
Second, they provide access to external resources (Hillman and Dalziel, 2003; Peng, 2004). Again, the second function is likely to be more important for the SMEs in our sample that have concentrated ownership. In general, different types of independent directors, such as bankers, venture capitalists, and politically-connected appointees, can bring different assets to the company or represent important stakeholders (Adams, Hermalin, and Weisbach, 2010). In China, for instance, companies sometimes appoint current and former government officials as independent directors for networking purposes (Peng, 2004; Tian and Lau, 2001), and this is also true of owners of private firms (Chen et al., 2012). Consequently, we hypothesize:

\section{H2b. Innovation performance is stronger for firms with independent directors.}

Outsider CEO. The agency-based theory of corporate governance generally suggests that the positions of CEO and Chair of the board should be separate Combining the positions (CEO-duality), it is argued, compromises the ability of the board to monitor the running of the firm (Fama, 1980; Fama and Jensen, 1983; Jensen, 1993; Coles, McWilliams, and Sen, 2001), because the single person can appoint friendly directors and stymie the flow of information (Westphal and Zajac, 1995; Monks and Minow, 2012). When the CEO and chairman are different persons, the boards of directors tend to be more independent and more effective in monitoring management (Mallette and Fowler, 1992), and firm performance tends to be better (Rechner and Dalton, 1991). This view is not universal, as stewardship theory argues that the separation between CEO and chairman may prevent unity and efficiency in decision-making (Donaldson and Davis, 1991; Finkelstein and D'Aveni, 1994).

The empirical literature on the effects of CEO-duality in developed countries has produced mixed evidence, with positive effects (Donaldson and Davis, 1991; Finkelstein and D'Aveni, 1994), negative effects (Rechner and Dalton, 1991; Mallette and Fowler, 1992), and insignificant results (Coles, McWilliams, and Sen, 2001) reported. The evi- 
dence from China on this issue is also mixed (Peng, Zhang, and Li, 2007). However, one result that does emerge from Song, Yuan, and Gao (2006) and Peng, Zhang, and Li (2007) is that the performance effects of combining the positions is positive for firms with a high level of state ownership, and negative for firms with a low level of state ownership. In SOEs, the chair and the CEO are both career-minded agents in the large state-centered hierarchy that includes government agencies and SOEs. In the hierarchy, the state is often unable or unwilling to specify well-defined objectives against which agents can be evaluated objectively. In order to gain promotion to better positions in other SOEs or the government, high-ranking officials in SOEs may engage in non-cooperative behaviors designed to foster their career progression. When the positions of Chair and CEO are separated, such behavior can harm coordination and efficiency in the organization. Therefore, in firms with dominant state ownership, the combination of the positions of Chair and CEO is valuable because it limits internal competition among senior executives and improves coordination and efficiency in decision-making.

However, in the case of our sample, the Chair is usually the largest shareholder in a highly concentrated private firm. Thus, there is little ambiguity about who holds the ultimate power in the firm, and the CEO is unlikely to disregard the will of the owner in decision-making. Hence, the coordination and efficiency advantages of combining the Chair and CEO positions are not necessarily present for SMEs with low or no state ownership. Nevertheless, consistent with the general case of Asia (Van Essen, van Oosterhout, and Carney, 2012), the founders of the company in our sample are often the dominant owners and Board Chairs, and they or their direct relatives serve as the CEO. While CEO-duality may promote the interests of the family, it may limit the benefits from hiring the best available professional managers that can be particularly large for innovative activities in SMEs. Accordingly, we hypothesize that:

\section{H3. The presence of outsider CEOs promotes innovation activity in privately}


owned firms. ${ }^{5}$

\section{Hypothesis testing}

\subsection{The Zhejiang Data and Context}

The data used in this paper come from a survey of firms in Zhejiang province, and in this section we discuss these data and the economic context that makes Zhejiang province relevant to this study. In 2012, Zhejiang's population (55 million) accounted for $4.0 \%$ of the national total, but its GDP ( $\$ 548$ billion $\left.^{6}\right)$ accounted for $6.7 \%$ of China's GDP $(\$ 8,227$ billion $)^{7}$. The GDP per head of Zhejiang is $\$ 10,022$, significantly higher than the national average of $\$ 6,076$. Among all provinces in 2012, the disposable income for urban residents and rural residents of Zhejiang ranked 3rd and 1st, respectively. The fraction of R\&D expenditure in Zhejiang's GDP was $2.04 \%$ in 2012, slightly higher than the national figure of $1.97 \%$. However, it appears R\&D expenditure in Zhejiang is especially productive, as patent grants to applicants in Zhejiang in $2010(188,000)$ accounted for $16.4 \%$ of the national total of patents granted to domestic applicants (1.14 million).

What truly distinguishes Zhejiang from other provinces is that Zhejiang's economy is highly market-oriented, and it boasts a private sector that is arguably the most vibrant and developed in China. For instance, $82.8 \%$ of enterprises in Zhejiang are non-state-owned and accounted for $82.9 \%$ of industrial output and $61.2 \%$ of employment in Zhejiang in 2012 . One key aspect underlying Zhejiang's strong private sector is therefore entrepreneurship.

\footnotetext{
${ }^{5}$ It would be interesting to determine whether the effects of an external CEO on innovation differs between SOEs and other firms by interacting a dummy variable for external CEOs with a dummy variable for SOEs. However, in our sample only one SOE firm separates the positions of chair and CEO. Consequently, we are unable to include such an interaction in regressions, and limit our hypothesis accordingly.

${ }^{6}$ Conversion into the US dollar is based on the average market exchange in the year. The same applies to all other currency conversions.

${ }^{7}$ Unless specified otherwise, the figures in this paragraph and the next are obtained from Statistical Communique of the People's Republic of China on the 2010 National Economic and Social Development, and Statistical Communique of the Zhejiang Province on the 2010 National Economic and Social Development. The urls for the communiques are http://www.stats.gov.cn/tjgb/ndtjgb/qgndtjgb/t20110228_402705692.htm and http://www.zhejiang.gov.cn/gb/zjnew/node3/node22/node170/node406/node6083/userobject9ai122219.html.
} 
As a province with relatively poor natural endowments, entrepreneurship is understood to play an important role in Zhejiang's economic success (Economist, 2011). One widely cited example of an entrepreneurial firm founded in Zhejiang is the Alibaba Group, an e-commerce firm of global recognition that handles more sales than eBay and Amazon.com combined (Economist, 2013). Therefore, Zhejiang constitutes an ideal context for studying private enterprise in China.

The survey from which this paper's data are obtained was carried out by the Association of Private Enterprises of Zhejiang Provincial Administration for Industry and Commerce (Zhejiangsheng Gongshangju Siying Qiye Xiehui) ${ }^{8}$ in 2007. The survey collected data on firm characteristics, innovation, compensation practices, corporate governance practices, and the characteristics of the chair of the board (usually the largest owner) for three years (2004, 2005 and 2006). Most firms covered were privately owned and in manufacturing industries. In some of our regressions, we exclude the SOEs, which account for less than $4 \%$ of the firms in our sample, because SOEs often receive favorable financing from banks, and they also benefit from government grants for R\&D. A total of 2400 surveys were sent and about 1920 were returned. To ensure data quality, six survey workers called selected firms to verify their data, and found $95 \%$ of the data entries were consistent. Therefore, we conclude that the quality of the surveys is high.

The majority of firms were in the manufacturing sector, and we restricted our sample to such firms. After eliminating firms with missing values for variables relevant to our hypotheses, our regression analysis involves an unbalanced panel of 370 firms and 725 firm-year observations, of which $86 \%$ are private. In addition, the vast majority are SMEs. In 2003, the National Development and Reform Commission of China defined SMEs in the manufacturing industry as firms with less than 2,000 employees, or with a revenue below 300 million yuan ( $\$ 36.2$ million), or with capital stock below 400 million yuan $(\$ 48$

\footnotetext{
${ }^{8}$ This was the name of the association at the time of survey. In 2009, the association was renamed as the Zhejiang Federation for Development of Non-state-owned Enterprises (Zhejiangsheng Minying Qiye Fazhan Lianhehui).
} 
million). Among the SMEs, firms with less than 300 employees, or with a revenue below 30 million yuan ( $\$ 3.6$ million), or with capital stock below 40 million yuan ( $\$ 4.8$ million) are small enterprises. Applying the 2003 definitions of SMEs in China to our 2004 sample, $56 \%$ of the firms are small enterprises, and $96 \%$ of the firms are small and medium-sized enterprises.

\subsection{Measurement}

The dependent variables are the number of new invention patents granted to a firm by the State Intellectual Property Office of China between 2004 and 2006, and new product sales of a firm in each year. The former is a measure that will include both product and process innovations, most likely of a technical nature. New products obviously do not include process innovations. A firm can acquire the designation of new products for some of its products through certification by central government or provincial governments. The new product sales measure the market success of a firm's innovation activity.

The independent variables are the size of the board, an indicator for whether a firm has independent directors, an indicator for whether a firm has a supervisory board, the shareholding of the largest shareholder, and an indicator for whether the CEO is an outsider. We define a CEO as an outsider if $\mathrm{s} /$ he is not the largest shareholder or a relative of the largest shareholder. We refer to the first three variables as the board-related governance variables.

Control variables include the log of R\&D expenditures, the fraction of senior managers who are subject to performance-based pay, log assets, log age of firms, and sector dummies. These are all well established in the innovation literature. We include the performance-based pay incentive for senior managers because may provide incentive for innovation. Log assets and the age of firm control for the effects the size and experience in production.

In all regressions, we include a measure or measures for past innovation activities to 
control for unobserved firm heterogeneity in innovation. For the patent equations, we use the stock of invention patents in 2004. In the regressions for new product sales, we use the number of patents in the same year and the one-year lag of new product sales. We include dummies to represent five major industrial groups to account for sector heterogeneity. Because we already use indicators of past innovation to control for unobserved firm heterogeneity in the regressions, we do not include dummies for more disaggregated industries to preserve degrees of freedom.

\subsection{Empirical Specification and Estimation}

The number of new invention patents is always non-negative. If a firms innovation efforts are not successful, it will report zero new invention patents. Between 2004 and 2006, $75.4 \%$ of firms do not report an increase in the number of patents owned. Because patents are a non-negative count variable, we estimate two models of patents, the Poisson model, and a Probit-Poisson hurdle model. ${ }^{9}$

The Poisson model is:

$$
\operatorname{Prob}\left(\text { patents }_{i, t}-\text { patent }_{i, t-2}\right)=f\left(X_{i, t-2}^{\prime} \beta\right)
$$

where $f$ is the Poisson function, $X$ is the vector of independent and control variables for firm $i$ as detailed in subsection 3.2, and $\beta$ is the vector of parameters. Since patenting usually lags the initial innovation efforts, in (1), we follow Lerner and Wulf (2007) to specify that independent and control variables in 2004 are related to new patents between 2004 and 2006.

The Poisson model assumes that the arrival of patents are independent events, hence the probability for a firm with zero patents to obtain the first patent is the same as the

\footnotetext{
${ }^{9}$ In unreported regressions, we also fitted a Probit-negative-binomial hurdle model to the data as an alternative. Based on log-likelihood and Akaike information criterion, the fit of the Probit-Poisson hurdle model is better. Consequently, we do not report the results from the Probit-negative-binomial hurdle model which are similar to the Probit-Poisson hurdle model.
} 
probability for a firm with five patents to obtain the sixth patent. Like many other productive activities, it is plausible that there exists learning-by-doing in innovation. For a firm without a patent, obtaining the first one through innovation is a substantial achievement. Once the firm has the first patent, the innovation experience gained can help the firm in further innovation, making future patents easier to obtain. Consequently, the stochastic process governing whether a firm obtains positive patents or not and the process governing the amount of patents conditional on a positive patent count can be different. To allow for the difference, we estimate a Probit-Poisson hurdle model. In the first part of the hurdle model, we estimate a Probit model in which the chance of obtaining positive patents depend on the independent variables and control variables

$$
\operatorname{Prob}\left(\text { patents }_{i, t}-\text { patent }_{i, t-2}>0\right)=\Phi\left(X_{i, t-2}{ }^{\prime} \gamma\right)
$$

where $\Phi$ is the density function for a normal distribution, $X$ is the same vector of variables as in equation (1), and $\gamma$ is the vector of parameters. Once a firm overcomes the innovation "hurdle" to obtain a positive patent count, we assume that conditional on $X$, the number of patents follows a truncated Poisson distribution. That is, the second part of the hurdle model is

$$
\operatorname{Prob}\left(\text { patents }_{i, t}-\text { patent }_{i, t-2} \mid \text { patent }_{i, t}-\text { patent }_{i, t-2}>0\right)=g\left(X_{i, t-2}{ }^{\prime} \delta\right)
$$

where $g$ is the distribution function for a zero-truncated Poisson distribution, $X$ is the same vector of variables as in equation (1), and $\delta$ is the vector of parameters.

One important issue in estimating the effects of governance on innovation is unobserved firm heterogeneity, which can potentially lead to biased estimates. For instance, if a firm has accumulated valuable know-how and experience in innovation, it is likely to choose endogenously to increase $R \& D$ inputs and adopt suitable corporate governance practices to boost innovation output. If such an initial advantage is not accounted for, an econometrician will overestimate the effect of $\mathrm{R} \& \mathrm{D}$ inputs and corporate governance on 
innovation by attributing the effect of initial advantage in innovation to R\&D inputs and corporate governance.

In general, the inclusion of random effects or fixed effects can mitigate the problem of unobserved heterogeneity in estimations based on panel data. Random effects can account for firm heterogeneity that is uncorrelated with the included independent and control variables. In linear regressions, fixed effects can control for unobserved heterogeneity that is constant and correlated with independent and control variables. Unfortunately, fixed effects cannot be included in the Probit, Poisson or Tobit models, because the nonlinearity in these models prevents identification and consistent estimation of the fixed effects.

The specification in equations (1) through (3) reduces our dataset to a simple crosssection, preventing us from including random effects. We control for unobserved firm heterogeneity by including the stock of patents in 2004. If a firm has an initial advantage in innovation, we expect it to be captured by the number of patents in 2004 .

As the case in many studies of corporate governance, the possibility of reverse causality complicates the interpretation of regression results (Börsch-Supan and Köke, 2002). To be specific, it is possible that firms with different innovative capacity choose different forms of corporate governance. Unfortunately, the nonlinear nature of the empirical model prevents us from identifying the causal effect of governance by implementing instrumental variable estimation. Consequently, although we try to use lag innovation indicators to account for firm heterogeneity in innovative capacity, caution is warranted in interpreting our empirical results.

The other dependent variable, new product sales, is also a non-negative variable and takes continuous values. In our sample, in 2004, 2005, and 2006, the percentages of firms who report zero new product sales are $52.9 \%, 47.6 \%$, and $45.7 \%$. Because the amount of new product sales is a non-negative continuous variable, we estimate two models, the conventional Type I Tobit model and the Lognormal hurdle Model. 
To be specific, the conventional Type I Tobit model, augmented with random effects, is

$$
\text { new product sales } s_{i, t}^{*}=X_{i, t}{ }^{\prime} \zeta+u_{i}+e_{i, t}
$$

where new product sales $i, t$ the latent measure of market success of innovation for firm $i$ in period $t, X$ is the vector of independent and control variables described in subsection $3.2, \zeta$ is the vector of parameters, $u_{i}$ is a firm specific random effect, and $e_{i, t}$ is the error term. As discussed in subsection 3.2, $X_{i, t}$ includes the number of patents in the same year and the one-year lag of new product sale. We only observe the new product sales $_{i, t}^{*}$ when it is positive:

$$
\begin{aligned}
& \text { new product sales } \text { pr,t }=\text { new product sales } s_{i, t}^{*} \quad \text { if new product sales } s_{i, t}^{*}>0 \\
& \text { new product sales } \text { pr,t }_{i, 0} \text { if new product sales } s_{i, t}^{*} \leq 0
\end{aligned}
$$

As noted in Wooldridge (2001), the Tobit model is restrictive in the sense that the same stochastic process governs whether we observe positive new product sale, and the amount of new product sale. For instance, the marginal effect of a variable on whether we observe new product sale and the marginal effect of the same variable on the amount of new product sale, must have the same sign. In our application, to report any new product sales, a firm must invest significantly in R\&D. However, when the new product is created, the actual sales amount is more likely to be influenced by the efforts of sales personnel. In general, the processes for creating and marketing new products need not be the same. The effects of corporate governance in these two processes can be different as well. To allow for different processes of developing and marketing new products, we estimate the Lognormal hurdle Model, which is a hurdle model for nonnegative continuous variables.

The first part of the Lognormal hurdle specifies a Probit model in which whether we observe positive new product sales depends on the vector of variables $X$ :

$$
\operatorname{Prob}\left(\text { new product } \text { sales }_{i, t}>0\right)=\Phi\left(X_{i, t}^{\prime} \eta\right)
$$


where $\Phi$ is the density function for a normal distribution, $X$ is the same vector of variables as in equation (4), and $\eta$ is the vector of parameters. For the second part of the Lognormal hurdle model, we estimate a log-normal model for observations with positive new product sales amount

$$
\text { new product sales } s_{i, t}=\exp \left(X_{i, t}^{\prime} \theta+v_{i, t}\right)
$$

where $X$ is the same vector of variables as in equation (4), and $\theta$ is the vector of parameters, and $v_{i t}$ is an error term following a normal distribution.

\section{Empirical Results}

\subsection{Summary statistics}

Table 1 presents the sample means, standard deviations, and the correlation matrix of the key variables. For all variables other than new invention patents, we compute the statistics for the years 2004, 2005, and 2006 combined. For new invention patents, we calculate the change in patents owned for each firm between 2004 and 2006.

On average, a firm in the sample has 1.32 invention patents. The average increase in patents owned between 2004 and 2006 was 0.84 . The average annual new product sales were 38.48 million yuan $(\$ 4.65 \text { million })^{10}$, while $R \& D$ expenditures were 4.65 million yuan (\$0.56 million) . The largest shareholder owned on average $56.41 \%$ of the shares of the firms, indicating a high level of ownership concentration in the medium and small enterprises. In the sample, $48 \%$ of the firms had independent directors, $72 \%$ had a supervisory board, and the average size of the board was about 4 directors. In only $9 \%$ of the observations did we observe that firms hired outsider CEOs. About $60 \%$ of managers are subject to performance-based pay. The firms are relative young, as the average age was about 10 years. Most of the firms are small or medium-sized, with an average asset level of 184 million yuan ( $\$ 22.22$ million). Most of the firms are private and domestically owned.

\footnotetext{
${ }^{10}$ All monetary figures are deflated with CPI to obtain values in 2004 yuan.
} 
Only about 5\% of firms are State-Owned Enterprises (SOEs), and about $10 \%$ are fully or partially Foreign-Owned Enterprises (FOEs).

\subsection{Regression results for Invention Patents}

Column (1) of Table 2 presents the Poisson model for new invention patents. Columns (2) and (3) present the first part (Probit) and second part (zero-truncated Poisson) of the Probit-Poisson hurdle model. The coefficients are the marginal effects of the righthand-side variables on the dependent variables, evaluated at the sample mean. The loglikelihood reported in column (3) is the combined log-likelihood of the two parts of regressions (presented in columns (2) and (3)). The same applies to the log-likelihood in column (6). Because the values of log-likelihood in columns (3) and (6) are higher than those in columns (1) and (3), respectively, the Probit-Poisson model and the lognormal hurdle model appear to fit the data better than the Poisson model and the Tobit model, respectively.

Regarding ownership concentration, we hypothesize in H1 that its effect on new invention patents is initially positive but becomes weaker at higher levels of concentration. To test this hypothesis (with ownership concentration measured by the shares owned by the largest shareholder), we specify its effect on patenting as piece-wise linear. To implement this specification, we include the variable shares owned by the largest shareholder (labeled largest sh \% in Table 2) and its interaction with a dummy variable indicating the shares owned by the largest shareholder is greater than $29 \%$ (labeled high concentration dummy in Table 2). We choose the threshold of $29 \%$ because this threshold value generates the highest log-likelihood value among the whole range of possible threshold values. In unreported regressions, we estimated a quadratic specification for ownership concentration, which results in a lower log-likelihood. In the first column of Table 2, when the ownership concentration level is below $29 \%$, the marginal effect of ownership concentration, which equals the coefficient on largest sh \%, is 0.06 and statistically significant. This implies if the 
share held by the largest owner increases by $10 \%$, the number of new invention patents will increase by 0.6 . When ownership concentration exceeds $29 \%$, its effect is equal to 0.01 , which is the sum of the coefficients on the variable largest sh $\%$ and the interaction term labeled high concentration dummy.largest sh \%. Although this effect of ownership concentration above the $29 \%$ threshold is still positive and statistically significant, it is markedly lower than the effect of ownership concentration below the threshold. When we switch to the Probit-Poisson hurdle model, we observe the same pattern in columns (2) and (3) in Table 2, although the coefficients are not significant in column (2). Overall, the results offer support for H1.

In $\mathrm{H} 2$, we argue that board size and presence of independent directors have positive effects on innovation (here measured by new invention patents). As shown in columns (1) through (3) of Table 2, both the Poisson model and the Probit-Poisson hurdle model indicate that the board size variable is always insignificant. Therefore, the results do not support $\mathrm{H} 2 \mathrm{a}$ (the positive effects of board size). As we discussed in the hypothesis development section, both board size and the characteristics of the board member may affect firms access to resources, and it is therefore possible that size alone is not an accurate measure of board effectiveness. Because the largest shareholders are dominant in firms in our sample, if they appoint insiders connected to them to control the board, then larger boards are not necessarily associated with greater resources. On the other hand, if the largest shareholders appoint outsiders to the board, it is more likely that larger boards give the firms greater access to external resources. In the first column (1) of Table 2, the Poisson model reports a positive and significant coefficient on independent directors. However, the positive effect of independent directors becomes insignificant in the ProbitPoisson model in columns (2) and (3) of Table 2. The results provide limited support for $\mathrm{H} 2 \mathrm{~b}$ (the positive effects of independent directors).

The last hypothesis, H3, argues that the presence of an external CEO will enhance 
innovation by providing professional services and by limiting family entrenchment. In the first two columns of Table 2, the coefficient on outsider CEO is insignificant. But it becomes marginally significant (with a p-value of 0.053) in the second part of the ProbitPoisson hurdle model. Therefore, in firms with a positive number of new patents, the results are consistent with our conjecture that the benefit of hiring professional external CEOs outweighs potential coordination problems created by the separation between CEO and chairman, because the dominance of the largest shareholder reduces such problems. The regression results weakly support H3.

To check whether our results are driven by the SOEs or FOEs, we drop these firms from the regressions and report the results in columns (1) through (3) in Table 3. The results are very similar to those in columns (1) through (3) in Table 2 , respectively. In columns (1) through (3) in Table 2, we also include dummy variables for SOEs and FOEs. These dummy variables are always insignificant. ${ }^{11}$ Overall, we conclude our results are not sensitive to the inclusion of SOEs and FOEs in the sample.

In summary, when we use patents as the measure for innovation, we see that H1, $\mathrm{H} 2 \mathrm{~b}$, and $\mathrm{H} 3$ receive support of different degrees, while H2a has no support.

\subsection{Regression Results for New Product Sales}

An alternative measure of innovation is new product sales, a measure widely used in previous studies of China (e.g. Li, Chen, and Shapiro, 2010). We estimate the Type I Tobit model and the Lognormal hurdle model with new product sales as the dependent variable, parallel to the equations for new invention patents. We present the results in columns (4) through (6) in Table 2. Column (4) corresponds to the Type I Tobit model, and columns (5) and (6) are the first (Probit) and second part (Lognormal) of the Lognormal hurdle model. Dropping SOEs and FOEs, we repeat the estimations and

\footnotetext{
${ }^{11}$ In columns (2) and (3), the SOE dummy is dropped from the regressions by Stata because of perfect linearity.
} 
report the results in columns (4) through (6) in Table 3. The coefficients are the marginal effects of the right-hand-side variables on the dependent variables, evaluated at the sample mean. Overall, we find little evidence that corporate governance variables have significant effects on new product sales. In these regressions, all coefficients on governance variables are not significant, except that the coefficient on external CEO in marginally significant and negative in column (5) of Table 2 and column (5) of Table 3.

\section{$5 \quad$ Summary and Discussion}

Chinese firms, and the Chinese government, have identified innovation as a path to future growth. Following the surge of innovation activities in China over the past decade, a new literature on innovation in China is emerging. In this paper we contribute to that literature by focusing on the question of whether corporate governance affects the innovation performance of firms in the emerging economy of China, with a specific focus on privately owned SMEs. We study a sample of 370 mostly private and relatively small firms in Zhejiang province, China between 2004 and 2006, using two measures of innovation, invention patents and new product sales, and a variety of estimation methods appropriate to each measure.

In general, we find that the impact of corporate governance on innovation depends on the measure of innovation activity. Some aspects of corporate governance are found to be related to innovation, when measured by new patents. We find relatively strong evidence that an increase in ownership concentration has a positive impact on innovation but the positive impact of additional concentration becomes smaller when concentration reaches a high level. Thus, the marginal effect of concentration on innovation is larger at lower level of ownership concentration. At the same time, there is some evidence that having independent members of the board and the presence of an external CEO positively affects invention patents granted to the firms, but board size has no impact. For the other 
measure of innovation, new product sales, we find no evidence that our corporate governance measures have any impact, indicating that more work is required to understand the nature and measurement of innovation in Chinese firms, and its relationship to corporate governance.

Although the evidence on the effects of corporate governance on innovation are not robust to the measure of innovation, we do find strong evidence that regardless of innovation measure, the innovation process does depend on R\&D investments (inputs) and that past innovation is a good predictor of future innovation. Thus, firms that invest in $R \& D$ are likely to be more innovative, and their success is likely to persist.

In terms of the literature on corporate governance and innovation, our study makes three contributions. First, we highlight the role of corporate governance in the innovation process in China. Existing studies on innovation in China focus on measurable inputs, in particular R\&D (Jefferson et al., 2006; Sun and Du, 2010; Wang and Kafouros, 2009; Li, Chen, and Shapiro, 2010). In this paper we focus on innovation outputs in China. Our findings do suggest that corporate governance might be an important determinant of innovation activity for SMEs in China, but only in a limited way, and future research should certainly be directly towards understanding why there is a difference in effects depending on the measure of innovation.

Second, because $86 \%$ of the firms in our sample are private and have no state or foreign ownership and $96 \%$ of the firms are SMEs, our paper focuses mainly on innovation in private SMEs whose future success is critical to China's economic transition and development. In China, the deliberate efforts of the Chinese government in promoting innovation, often via the public sector, have not been effective (Breznitz and Murphree, 2011, p.28). Relative to other types of enterprise, state-owned enterprises (SOEs) were found to have lower R\&D inputs and outputs (Jefferson et al., 2003). At the same time, as the private sector has become a more important force in China's economy, private firms 
have become the most important source of China's innovation (Huang, 2010). The Chinese government itself also recognizes the important role of private firms in innovation (Breznitz and Murphree, 2011, p.77). Situated in Zhejiang, our study offers an opportunity to understand the innovative activities of what are among the most vibrant private Chinese firms. In this sense, it is important that our sample firms do indeed innovate, and that in important respects the determinants of innovation are similar to those observed in developed countries. In particular, our results suggest that innovative activity is related to $\mathrm{R} \& \mathrm{D}$ inputs, and that innovative activity is persistent, results consistent with those in developed countries (Geroski, Van Reenen, and Walters, 1997; Cefis and Orsenigo, 2001; Cefis, 2003; Raymond et al., 2010). Thus, innovation in these firms is not random, and the persistence results suggest that future research on Chinese firms may wish to focus on this feature of successful innovation.

Third, our result adds to the literature on corporate governance and innovation by focusing on an emerging market. Current knowledge on corporate governance and innovation is based mostly on theory developed in the context of developed countries and evidence from developed countries (Belloc, 2012). We argue the many corporate governance factors should have similar positive effects on innovation in the SMEs in emerging economies. However, because the SMEs feature both high levels of ownership concentration and restricted access to external resources, the effects of corporate governance on innovation are more likely to originate from the need to access resources, rather than because of the need for efficient monitoring. In the business environment of an emerging economy, if the market institutions and legal system are less supportive of innovation, the internal governance of a firm will play a more important role in achieving its innovative goals by pulling together resources and by engaging stakeholders. The empirical findings in our paper provide only very limited evidence consistent with the literature based on developed countries, suggesting that the relation between corporate governance and inno- 
vation may be somewhat different and complex in emerging economies, and will require further study. While we have not been able to establish a strong uniform role for board governance, there is at least some evidence that it might matter. There is certainly quite strong evidence that ownership structure matters, particularly for patenting activities.

The relatively stronger effects of corporate governance on the number of invention patents, as compared to its impact on new product sales, requires further comment. First, invention patents and new product sales are very different forms of innovation. Invention patents likely represent a more radical form of innovation because to be considered for registration, innovations must be judged to represent a marked improvement over past patents and knowledge. In contrast, new products are often incremental innovations, because they can result from modification of existing products, and the commercialization of invention patents. Corporate governance may be better suited to support radical innovation efforts that require strategic, purposefully, and long-term planning. Second, new product sales are likely to involve more stakeholders, often at the operational level, and it is hard for the usual corporate governance practices to target these effectively. Besides the top management team and $R \& D$ workers, success in new product sales also requires inputs from marketing and sales personnel. The governance factors considered in our paper (the board-related factors, ownership concentration, and the presence of an external CEO) are not meant to provide direct incentives to all involved individuals.

Of course, these remain our speculative thoughts on the relationship between corporate governance and new product sales. The existing literature does offer some information about the determination of new product sales. Li, Chen, and Shapiro (2010) find that spillovers from foreign firms contribute to higher new product sales in domestically owned Chinese firms. Apparently, future work is needed to understand the determination of invention patents, the determination of new product sales, and the interactions between the two processes. 
Another possible reason for the lack of a strong relation between corporate governance and new product sales is that new product sales can be a very noisy measure of innovation. As discussed by Xiao, Tylecote, and Liu (2013), Chinese firms face four options in innovative strategies. They can rely on technology transfer from frontier firms, imitation of frontier firms, the creation differentiated products that are not novel, or the creation of genuinely novel new products. Although these four strategies can lead to substantial differences in long-term innovation capacity, the adoption of any one of the strategies can lead Chinese firms to produce more new products. Therefore, despite the popularity of new product sales as a measure of innovative capacity in studies of innovation in China, there are reasons to be cautious about its use. We use the new product sales as a dependent variable to facilitate comparison to other studies, but we speculate that our results suggest more about this measure than they do about the effects of corporate governance on dynamic innovative capabilities. To the extent that our results point to the restrictive nature of new product sales as a measure, future studies should carefully consider the measure of innovation that they choose.

The focus of our sample on private SMEs provides interesting insights, but it has its own limitations and hence warrants caution in interpreting the results. First, although Zhejiang provides a good background for the study of private SMEs, it is not the average province in China because the role of the private sector in Zhejiang is much more significant compared to other provinces. Consequently, our results may not readily extend to private SMEs in other provinces in China, where private firms may face a business environment that is less friendly to the private sector. However, studying Zhejiang does help us to understand the innovative potential of private SMEs in China in general, especially as their business environment improves with further market-oriented reforms.

In general, our results do suggest that corporate governance and ownership have an impact on long-run innovation capabilities of small firms. There will be ample research 
opportunities to study the effects of corporate governance on innovation and other aspects of firm performance across China as economic reforms proceed and the role of private sector firms, large and small, becomes better established. 


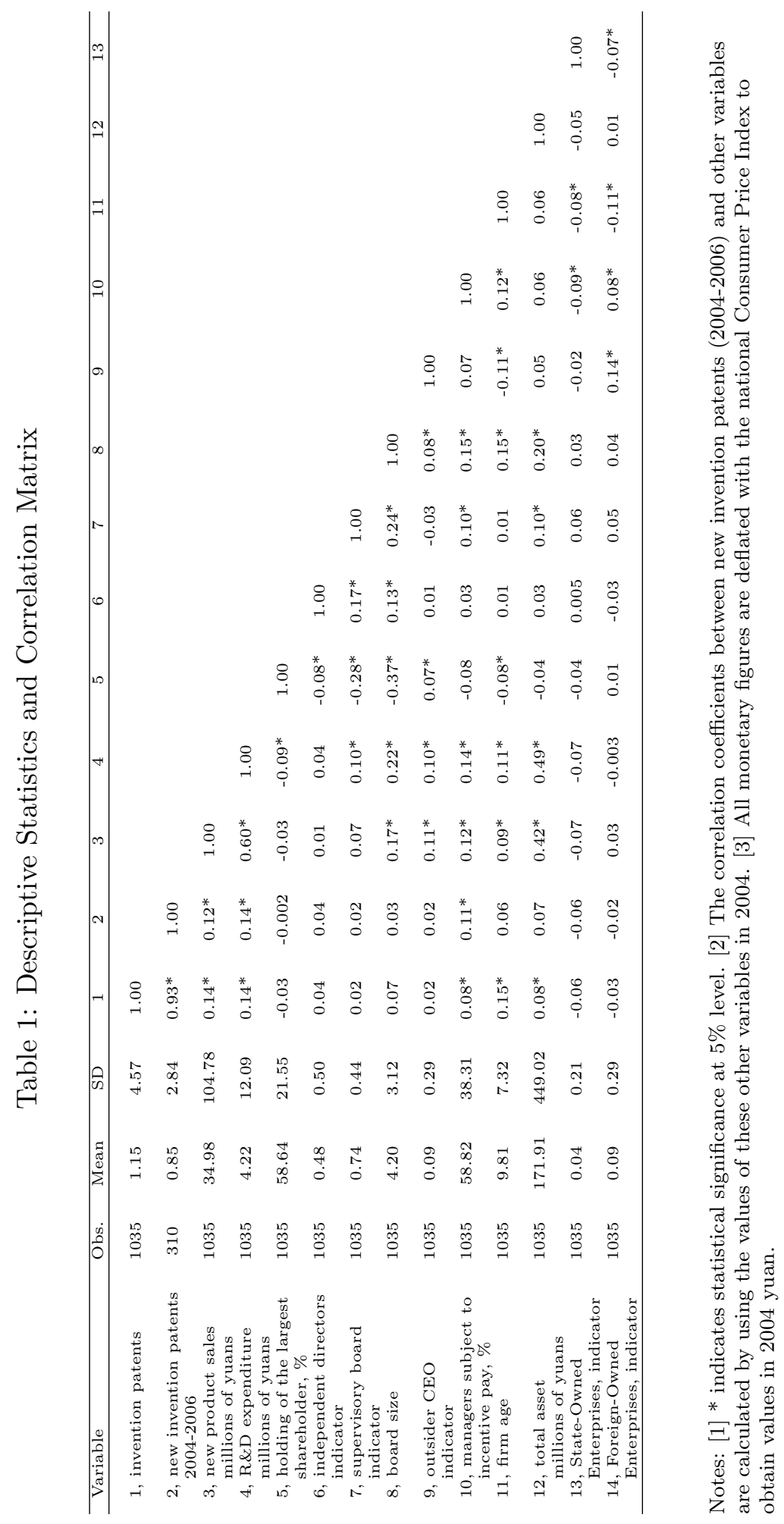




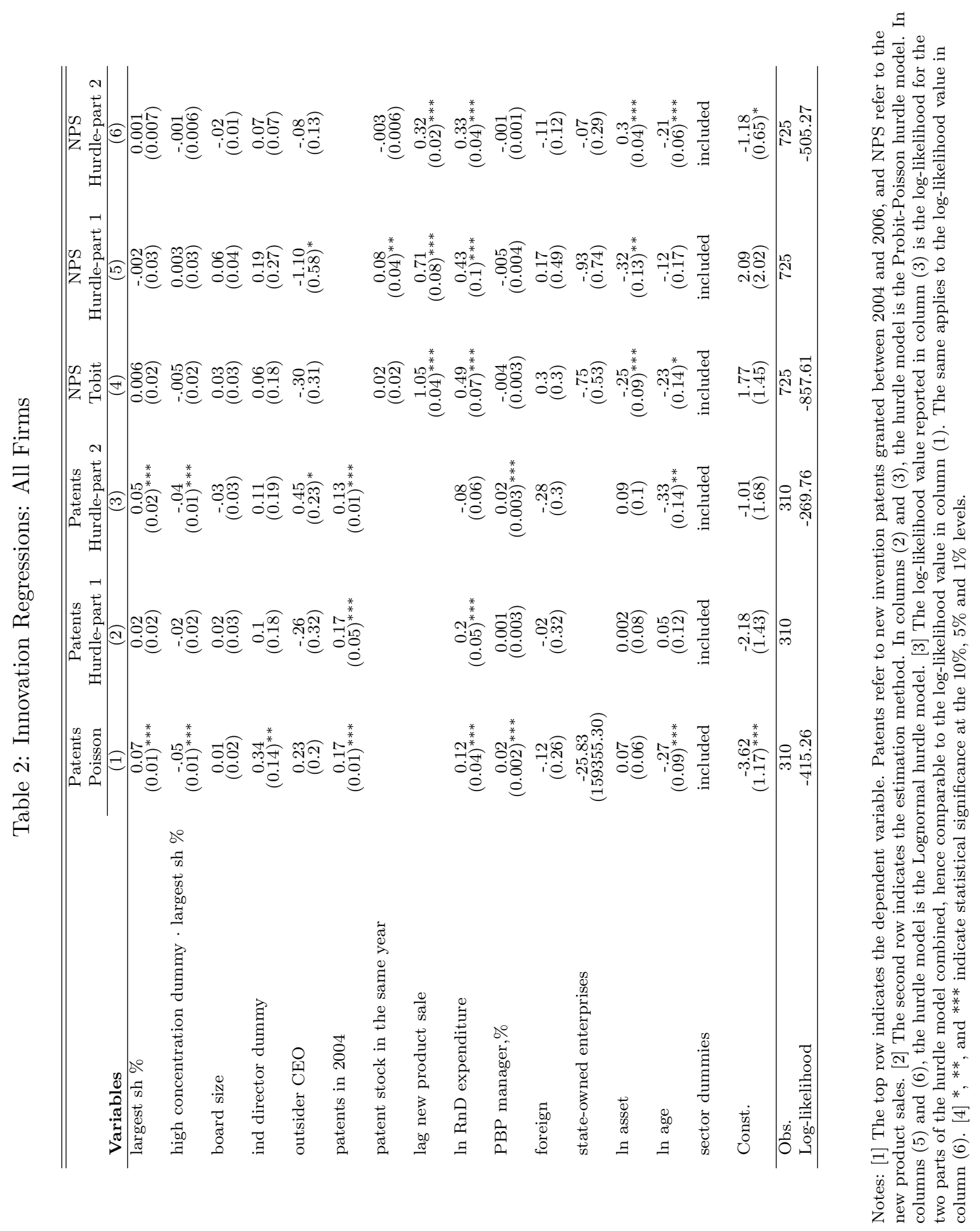




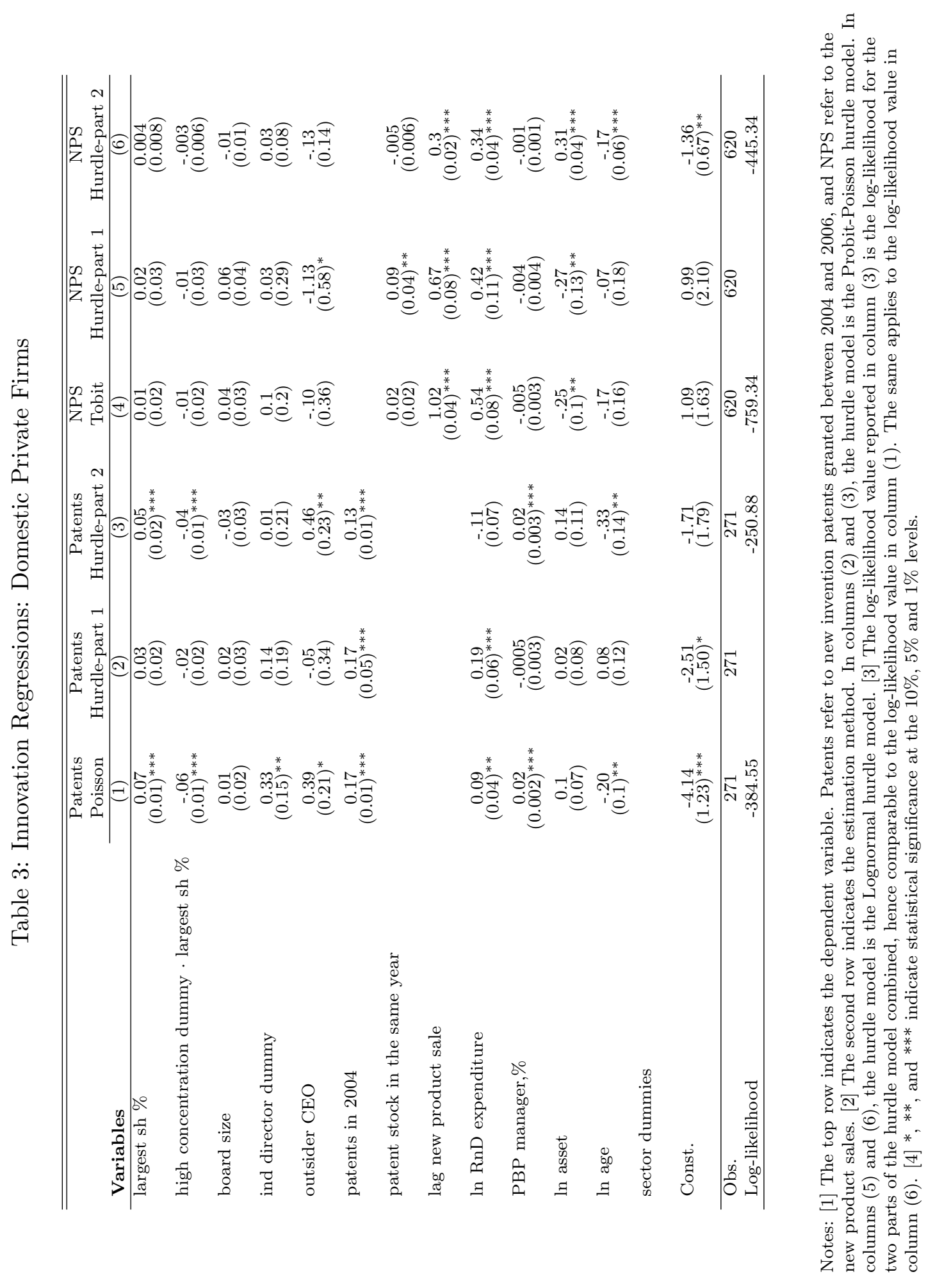




\section{References}

Adams, R. B., B. E. Hermalin, and M. S. Weisbach (2010). The role of boards of directors in corporate governance: A conceptual framework and survey. Journal of Economic Literature 48(1), 58-107.

Aghion, P., J. Van Reenen, and L. Zingales (2013, September). Innovation and institutional ownership. American Economic Review 103(1), 277-304.

Alchian, A. A. and H. Demsetz (1972). Production, information costs, and economic organization. The American Economic Review 62(5), 777-795.

Backman, M. (1999). Asian eclipse: Exposing the dark side of business in Asia. J. Wiley Singapore/New York.

Barclay, M. J. and C. G. Holderness (1989). Private benefits from control of public corporations. Journal of financial Economics 25(2), 371-395.

Barclay, M. J. and C. G. Holderness (1991). Negotiated block trades and corporate control. The Journal of Finance 46(3), 861-878.

Barclay, M. J., C. G. Holderness, and J. Pontiff (1993). Private benefits from block ownership and discounts on closed-end funds. Journal of Financial Economics 33(3), $263-291$.

Baysinger, B. and R. E. Hoskisson (1990). The composition of boards of directors and strategic control: Effects on corporate strategy. The Academy of Management Review $15(1)$, pp. $72-87$.

Baysinger, B., R. Kosnik, and T. Turk (1991). Effects of board and ownership structue on corporate r\&d strategy. Academy of Management Journal 34(1), 205-214. 
Belloc, F. (2012). Corporate governance and innovation: A servey. Journal of Economic Surveys 26(5), 835-864.

Börsch-Supan, A. and J. Köke (2002). An applied econometricians' view of empirical corporate governance studies. German Economic Review 3(3), 295-326.

Breznitz, D. and M. Murphree (2011, May). Run of the Red Queen: Government, Innovation, Globalization, and Economic Growth in China. New Haven, CN, USA: Yale University Press.

Bushee, B. (1998). The influence of institutional investors on myopic r\&d investment behavior. Accounting review, 305-333.

Byrd, J. and K. Hickman (1992). Do outside directors monitor managers?: Evidence from tender offer bids. Journal of Financial Economics 32(2), 195-221.

Casper, S. and C. Matraves (2003). Institutional frameworks and innovation in the german and uk pharmaceutical industry. Research Policy 32(10), 1865 - 1879.

Cefis, E. (2003). Is there persistence in innovative activities? International Journal of Industrial Organization 21(4), 489 - 515.

Cefis, E. and L. Orsenigo (2001). The persistence of innovative activities: A cross-countries and cross-sectors comparative analysis. Research Policy 30(7), 1139 - 1158.

Chang, S. J. and J. Hong (2000). Economic performance of group-affiliated companies in korea: Intragroup resource sharing and internal business transactions. Academy of Management Journal, 429-448.

Chen, V. Z., J. Li, and D. M. Shapiro (2011). Are oecd-prescribed "good corporate governance practices" really good in an emerging economy? Asia Pacific Journal of Management 28(1), 115-138. 
Chen, V. Z., X. Zhang, J. Li, and D. M. Shapiro (2012). Ownership structure and innovation performance: An emerging-market perspective. Available at SSRN 1299737.

Chen, Z., Y. Sun, A. Newman, and W. Xu (2012). Entrepreneurs, organizational members, political participation and preferential treatment: Evidence from china. International Small Business Journal 30(8), 873-889.

Choi, S. B., S. H. Lee, and C. Williams (2011). Ownership and firm innovation in a transition economy: Evidence from china. Research Policy 40(3), $441-452$.

Choi, S. B., B. I. Park, and P. Hong (2012). Does ownership structure matter for firm technological innovation performance? the case of korean firms. Corporate Governance: An International Review 20(3), 267-288.

Chow, I. H.-S. and S. S. Liu (2007). Business strategy, organizational culture, and performance outcomes in china's technology industry. Human Resource Planning 30(2), 47 55.

Claessens, S. and J. P. Fan (2002). Corporate governance in asia: A survey. International Review of Finance 3(2), 71-103.

Coles, J. W., V. B. McWilliams, and N. Sen (2001). An examination of the relationship of governance mechanisms to performance. Journal of Management 27(1), 23-50.

Conyon, M. J. and S. I. Peck (1998). Board size and corporate performance: evidence from european countries. The European Journal of Finance 4(3), 291-304.

Demb, A., F. Neubauer, et al. (1992). The corporate board: Confronting the paradoxes. Long Range Planning 25(3), 9-20.

Deng, Z., P. S. Hofman, and A. Newman (2013). Ownership concentration and product innovation in chinese private smes. Asia Pacific Journal of Management 30(3), 717-734. 
Donaldson, L. and J. H. Davis (1991). Stewardship theory or agency theory: Ceo governance and shareholder returns. Australian Journal of Management 16(1), 49-64.

Driver, C. and M. J. C. Guedes (2012). Research and development, cash flow, agency and governance: Uk large companies. Research Policy 41(9), 1565-1577.

Eng, L. L. and M. Shackell (2001). The implications of long-term performance plans and institutional ownership for firms' research and development (r\&d) investments. Journal of Accounting, Auditing $\&$ Finance 16(2), 117-139.

Faccio, M., L. H. Lang, and L. Young (2001). Dividends and expropriation. American Economic Review, 54-78.

Fama, E. F. (1980). Agency problems and the theory of the firm. The Journal of Political Economy, 288-307.

Fama, E. F. and M. C. Jensen (1983). Agency problems and residual claims. JL $\mathscr{E}$ Econ. 26, 327.

Fich, E. M. (2005). Are some outside directors better than others? evidence from director appointments by fortune 1000 firms. The Journal of Business 78(5), pp. 1943-1972.

Fich, E. M. and A. Shivdasani (2006). Are busy boards effective monitors? The Journal of Finance 61(2), 689-724.

Finkelstein, S. and R. A. D'Aveni (1994). Ceo duality as a double-edged sword: How boards of directors balance entrenchment avoidance and unity of command. Academy of Management Journal, 1079-1108.

Geroski, P. A., J. Van Reenen, and C. F. Walters (1997). How persistently do firms innovate? Research Policy 26(1), 33-48. 
Gibson, M. S. et al. (2003). Is corporate governance ineffective in emerging markets? Journal of Financial and Quantitative Analysis 38(1), 231-250.

Handoko, F., A. Smith, and C. Burvill (2014). The role of government, universities, and businesses in advancing technology for smes innovativeness. Journal of Chinese Economic and Business Studies 12(2), 171-180.

Hermalin, B. E. (2005). Trends in corporate governance. The Journal of Finance 60(5), $2351-2384$.

Hermalin, B. E. and M. S. Weisbach (1998). Endogenously chosen boards of directors and their monitoring of the ceo. The American Economic Review 88(1), pp. 96-118.

Hermalin, B. E. and M. S. Weisbach (2003). Boards of directors as an endogenously determined institution: a survey of the economic literature. Economic Policy Review (Apr), $7-26$.

Heugens, P. P., M. Van Essen, and J. H. van Oosterhout (2009). Meta-analyzing ownership concentration and firm performance in asia: Towards a more fine-grained understanding. Asia-Pacific Journal of Management 26(3), 481-512.

Hill, C. W. and S. A. Snell (1988). External control, corporate strategy, and firm performance in research-intensive industries. Strategic Management Journal 9(6), 577-590.

Hillman, A. J. and T. Dalziel (2003). Boards of directors and firm performance: Integrating agency and resource dependence perspectives. The Academy of Management Review, $383-396$.

Hölmstrom, B. (1979). Moral hazard and observability. The Bell Journal of Economics 10(1), pp. 74-91.

Hölmstrom, B. (1982). Moral hazard in teams. The Bell Journal of Economics, 324-340. 
Hölmstrom, B. and P. Milgrom (1994). The firm as an incentive system. The American Economic Review 84(4), pp. 972-991.

Hu, A. G. and G. H. Jefferson (2009). A great wall of patents: What is behind china's recent patent explosion? Journal of Development Economics 90(1), 57 - 68.

Hu, J. (2007, October 15). Hold high the great banner of socialism with chinese characteristics and strive for new victories in building a moderately prosperous society in all respects. Speech by hu jintao to the seventeenth national congress, Beijing.

Huang, K. G. (2010). China's innovation landscape. Science 329, 632-633.

Jefferson, G., A. G. Hu, X. Guan, and X. Yu (2003). Ownership, performance, and innovation in china's large- and medium-size industrial enterprise sector. China Economic Review (1043951X) 14(1), 89.

Jefferson, G. H., H. Bai, X. Guan, and X. Yu (2006). R\&d performance in chinese industry. Economics of Innovation \& New Technology 15(4/5), $345-366$.

Jensen, M. C. (1993). The modern industrial revolution, exit, and the failure of internal control systems. The Journal of Finance 48(3), 831-880.

Jensen, M. C. and W. H. Meckling (1976). Theory of the firm: Managerial behavior, agency costs and ownership structure. Journal of Financial Economics 3(4), 305 - 360.

Khanna, T. and J. W. Rivkin (2000). Estimating the performance effects of business groups in emerging markets. Strategic management journal 22(1), 45-74.

La Porta, R., F. López-de Silanes, A. Shleifer, and R. Vishny (2000). Investor protection and corporate governance. Journal of financial economics 58(1), 3-27.

Lacetera, N. (2001). Corporate governance and the governance of innovation: The case of pharmaceutical industry. Journal of Management and Governance 5, 29-59. 
Lee, P. M. (2005). A comparison of ownership structures and innovations of us and japanese firms. Managerial and Decision Economics 26(1), 39-50.

Lehn, K. M., S. Patro, and M. Zhao (2009). Determinants of the size and composition of us corporate boards: 1935-2000. Financial Management 38(4), 747-780.

Lerner, J., M. Sorensen, and P. Stromberg (2008, December). Private equity and longrun investment: The case of innovation. Working Paper 14623, National Bureau of Economic Research.

Lerner, J. and J. Wulf (2007, 07). Innovation and incentives: Evidence from corporate r\&d. The Review of Economics and Statistics 89(4), 634-644.

Li, J., D. Chen, and D. M. Shapiro (2010). Product innovations in emerging economies: The role of foreign knowledge access channels and internal efforts in chinese firms. Management \& Organization Review 6(2), 243 - 266.

Li, Y., C. Zhang, Y. Liu, and M. Li (2010). Organizational learning, internal control mechanisms, and indigenous innovation: The evidence from china. IEEE Transactions on Engineering Management 57(1), $63-77$.

Linck, J. S., J. M. Netter, and T. Yang (2008). The determinants of board structure. Journal of Financial Economics 87(2), 308-328.

Linck, J. S., J. M. Netter, and T. Yang (2009). The effects and unintended consequences of the sarbanes-oxley act on the supply and demand for directors. Review of Financial Studies 22(8), 3287-3328.

Lipton, M. and J. W. Lorsch (1992). A modest proposal for improved corporate governance. The Business Lawyer, 59-77. 
Liu, X., M. Wright, and I. Filatotchev (2013). Learning, firm age and performance: An investigation of returnee entrepreneurs in chinese high-tech industries. International Small Business Journal, 0266242613508147.

Mace, M. L. (1971). Directors: Myth and reality. Division of Research, Graduate School of Business Administration, Harvard University.

Mallette, P. and K. L. Fowler (1992). Effects of board composition and stock ownership on the adoption of" poison pills". Academy of Management Journal 35(5), 1010-1035.

Mayer, C. (1997). The city and corporate performance: condemned or exonerated? Cambridge Journal of Economics 21(2), 291-302.

Miozzo, M. and P. Dewick (2002). Building competitive advantage: innovation and corporate governance in european construction. Research policy 31 (6), 989-1008.

Monks, R. A. and N. Minow (2012). Corporate governance. Wiley.

Morck, R. and B. Yeung (2004). Family control and the rent-seeking society. Entrepreneurship Theory and Practice 28(4), 391-409.

Newman, A., S. Gunessee, and B. Hilton (2012). Applicability of financial theories of capital structure to the chinese cultural context: A study of privately owned smes. International Small Business Journal 30(1), 65-83.

Peng, M. W. (2004). Outside directors and firm performance during institutional transitions. Strategic Management Journal 25(5), 453-471.

Peng, M. W., S. Zhang, and X. Li (2007). Ceo duality and firm performance during china's institutional transitions. Management and Organization Review 3(2), 205-225.

Pfeffer, J. and G. Salancik (2003). The external control of organizations: A resource dependence perspective. Stanford Business Books. 
Rajan, R. G. and L. Zingales (1998). Which capitalism? lessons form the east asian crisis. Journal of Applied Corporate Finance 11(3), 40-48.

Raymond, W., P. Mohnen, F. Palm, and S. S. Van Der Loeff (2010). Persistence of innovation in dutch manufacturing: Is it spurious? The Review of Economics and Statistics 92(3), 495-504.

Rechner, P. L. and D. R. Dalton (1991). Ceo duality and organizational performance: A longitudinal analysis. Strategic Management Journal 12(2), 155-160.

Rosenstein, S. and J. G. Wyatt (1990). Outside directors, board independence, and shareholder wealth. Journal of Financial Economics 26(2), 175-191.

Sapra, H., A. Subramanian, and K. Subramanian (2011). Corporate governance and innovation: Theory and evidence. In 3rd Annual Conference on Empirical Legal Studies Papers, pp. 08-05.

Song, F., P. Yuan, and F. Gao (2006). Does large state shareholder affect the governance of chinese board of directors? Working paper (in chinese), Tsinghua University, Beijing.

Su, Y., D. Xu, and P. H. Phan (2008). Principal-principal conflict in the governance of the chinese public corporation. Management and Organization Review 4(1), 17-38.

Sun, Y. and D. Du (2010). Determinants of industrial innovation in china: Evidence from its recent economic census. Technovation 30(9-10), $540-550$.

Tian, J. J. and C.-M. Lau (2001). Board composition, leadership structure and performance in chinese shareholding companies. Asia Pacific Journal of Management 18(2), $245-263$

Tsui, A. S. (2006). Contextualization in chinese management research. Management and Organization Review 2(1), 1-13. 
Ughetto, E. (2010). Assessing the contribution to innovation of private equity investors: A study on european buyouts. Research Policy 39(1), 126-140.

Van Essen, M., J. H. van Oosterhout, and M. Carney (2012). Corporate boards and the performance of asian firms: A meta-analysis. Asia Pacific Journal of Management 29(4), 873-905.

Wang, C. and M. I. Kafouros (2009). What factors determine innovation performance in emerging economies? evidence from china. International Business Review 18(6), 606 616.

Westphal, J. D. and E. J. Zajac (1995). Who shall govern? ceo/board power, demographic similarity, and new director selection. Administrative Science Quarterly, 60-83.

Williamson, O. E. (1988). Corporate finance and corporate governance. The journal of finance 43(3), 567-591.

Wooldridge, J. M. (2001, June). Econometric Analysis of Cross Section and Panel Data. Number 0262232197 in MIT Press Books. The MIT Press.

Wu, H.-L. (2008). When does internal governance make firms innovative? Journal of Business Research 61(2), 141-153.

Xiao, Y., A. Tylecote, and J. Liu (2013). Why not greater catch-up by chinese firms? the impact of ipr, corporate governance and technology intensity on late-comer strategies. Research Policy 42(3), 749-764.

Xinhua (2013, February). Vice premier pledges support for china's smes. Online.

$\mathrm{Xu}, \mathrm{X}$. and Y. Wang (1999). Ownership structure and corporate governance in chinese stock companies. China economic review 10(1), 75-98. 
Yang, J., H. Liu, S. Gao, and Y. Li (2012). Technological innovation of firms in china: Past, present, and future. Asia Pacific Journal of Management 29(3), 819-840.

Young, M. N., M. W. Peng, D. Ahlstrom, G. D. Bruton, and Y. Jiang (2008). Corporate governance in emerging economies: A review of the principal-principal perspective. Journal of Management Studies 45(1), 196-220.

Zhang, Y.-C. and S.-L. Li (2009). High performance work practices and firm performance: evidence from the pharmaceutical industry in china. International Journal of Human Resource Management 20(11), 2331 - 2348.

Zhao, Y. Y., P. K. Wong, A. M. Subramanian, and C.-C. Hang (2014). Technology licensing and innovation performance: evidence from chinese latecomers in high-tech industries. Journal of Chinese Economic and Business Studies 12(2), 125-147.

Zhu, Y., X. Wittmann, and M. W. Peng (2012). Institution-based barriers to innovation in smes in china. Asia Pacific Journal of Management 29(4), 1131-1142. 